DOI:

UDC 669.013.002.5:531.3

O.O. Beygul, Doctor of Engineering Science, full professor, dstu.mo@i.ua

D.I. Grischenko, Post-graduate student, dstu.mo@i.ua

V.O. Beygul, Candidate of Engineering Science, associate Professor, dstu.mo@i.ua

D.B. Sereda, Candidate of Engineering Science, senior lecturer, dstu.mo@i.ua

Dniprovsky state technical university, Kamianske

\title{
INVESTIGATION OF BAND LOOP FRAME ARTICULATED CONTEINER TRUCK STABILITY BY MOTION ON THECHNOLOGICAL ROADS
}

Mathematical model of disturbance motion for articulated container truck with band loop frame on pneumatic wheels by different conditions of cross stabilization has been worked out by analytical mechanics method with Lagrange equation of second type. Analytical expressions of critical parameters of system, which define stability of articulated container truck in cross plane has been received.

Keywords: mathematical model, stability, articulated container truck, disturbance motion, band loop frame.

У роботі розроблена математична модель збуреного руху зчленованого контейнеровоза з бугельною рамою на пневмоколісному ході при різних умовах поперечної стабілізації методами аналітичної механіки з залученням рівняння Лагранжа другого роду. Отримані аналітичні вирази критичних швидкостей, які містять у собі параметри системи, щэо визначають стійкість зчленованого контейнеровоза у поперечній площині.

Ключові слова: математична модель, стійкість, зчленований контейнеровоз, збурений рух, бугельна рама.

\section{The statement of the problem}

The advancement of the metallurgical industry is closely linked to the continued growth of mechanization and automation of transport operations along technological lines, where new tasks are being set in the way of development of promising models of special vehicles. Thus, for carrying out operations related to the autonomous loading, transportation and unloading of containers, it is advisable to layout the carrier system with a tow frame.

The rowing layout of the carrier systems of technological vehicles is quite unconventional. As the review of the literature shows, only a few scientific works are devoted to such machines. If for the usual layout, especially in the general automotive industry, we have accumulated a wealth of experience in the development of mathematical models of perturbed motion, the formation of external loads, internal efforts, then for articulated container ships on a pneumatic wheel course with a tow frame everything has to be done for the first time.

For scientifically sound choice of such carrier systems, dynamic loads play a decisive role, the formation of which is described by a mathematical model of the process of perturbed motion of a container ship in conditions of technological roads of metallurgical production.

\section{Analysis of basic research and publications}

The development and construction of container transporters with a tow frame are in the initial stages of development, so we consider the problem from a more general point of view. Thus, works [1-3] are devoted to the study of special vehicles for the transport of goods in containers and packages in various industries. The work [4,5] dedicated to the design and construction of articulated skid steer carriers is of course preceded by a fundamental work [6] to investigate the dynamics of self-propelled swivel machines, including oscillation and movement stability. The works [7-9] are devoted to the dynamics of two-link mechanical systems, which according to the calculation schemes are similar to articulated containers with a tow frame. The work [10] is devoted to the study of the dynamics of perturbed motion of an articulated special vehicle with a $U$ - shaped cargo frame. 


\section{Formulation of the purpose of the study}

From the above analysis, it follows that the known mathematical models of the perturbed motion of technological special vehicles do not take into account the layout features of articulated containers with a tow carrier system. There are practically no materials in the scientific literature devoted to the research and development of metallurgical container ships with a tow frame, with the obvious relevance of such machines in technological lines of metallurgical enterprises.

Thus, it is possible to formulate the following research goal: to find out the influence of the stabilizer of lateral stability in the elastic suspension of the tow frame on the critical stability of the speed of movement of a container ship with different level of stabilization.

\section{The main material}

Shown in Fig. In Fig. 1 an articulated container vessel with a tow frame on the side, shown in Fig. 2 shows the design scheme of the container carrier on the rear view.

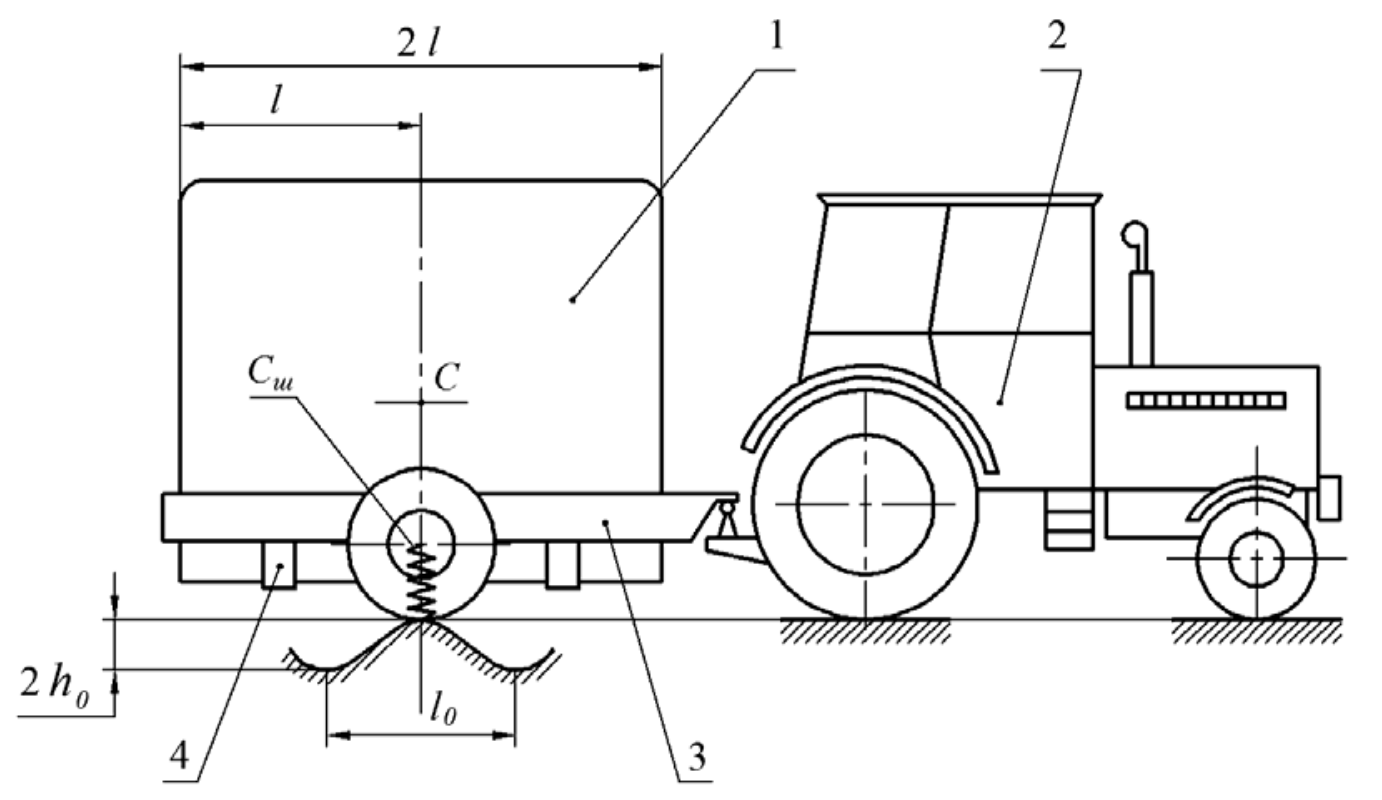

Fig. 1. Articulated container ship with a tow frame: $1-$ container; $2-$ tractor; $3-$ semitrailer with tow frame; 4 - lodging

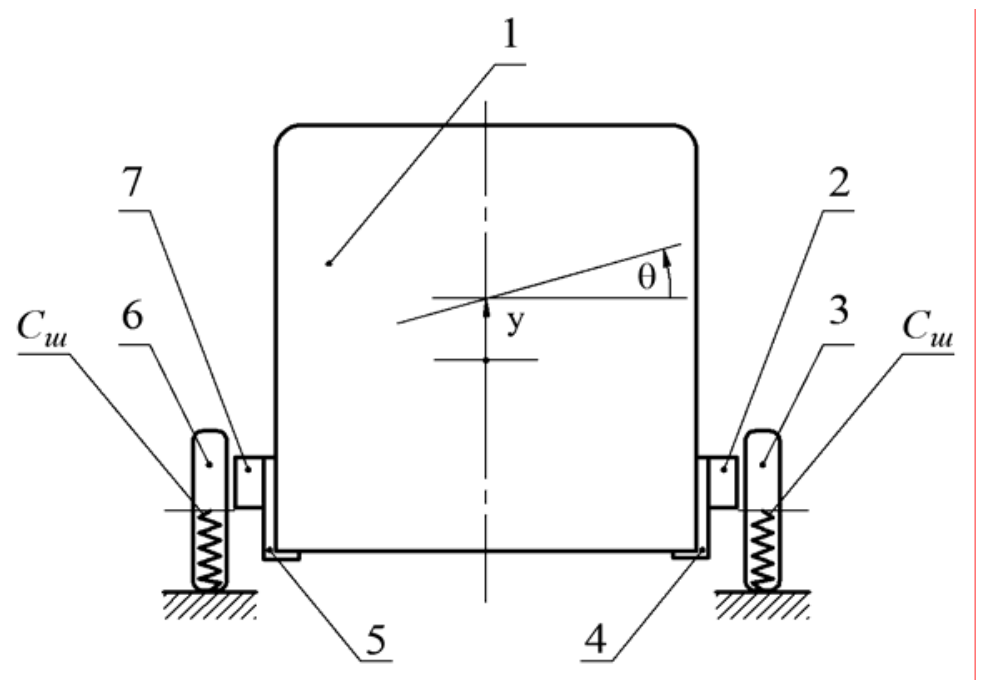

Fig. 2. The articulated container vessel on the rear view: 1 - container; 2 - right frame spar; 3 right wheel of a semi-trailer suspension; 4 - right lodgment; 5 - left lodging; 6 - left semi-trailer suspension wheel; 7 - left frame spar 
The perturbation equation is obtained in the form of the second-kind Lagrange equation [11].

$$
\frac{d}{d t}\left(\frac{\partial T}{\partial \dot{q}_{j}}\right)-\frac{\partial T}{\partial q_{j}}=-\frac{\partial \Pi}{\partial q_{j}}+Q_{j},
$$

where $T$ - the kinetic energy of the system, $\mathrm{J} ; \Pi$ - the potential energy of the system, $\mathrm{J} ; \quad q_{j}-$ $j$-a the generalized coordinate, $\mathrm{m}(\mathrm{rad}) ; Q_{j}-j$-a the generalized force of non-conservative origin, $\mathrm{N}$ $(\mathrm{N} \cdot \mathrm{m})$.

In this case $q_{1}=y, q_{2}=\theta$, where $y$ - vertical displacementof the semi-trailer, a $\theta$ - the angle of the semi-trailer in the transverse plane.

The kinetic energy of the system:

$$
T=\frac{m_{c} \dot{y}^{2}}{2}+\frac{I_{c} \dot{\theta}^{2}}{2}+\frac{m_{c} v^{2}}{2}
$$

where $m_{c}$ - the total mass of the semi-trailer, $\mathrm{kg} ; I_{c}$ - semitrailer total moment of inertia relative to the longitudinal axis, which runs through the center of mass of the system, $\mathrm{kg} \cdot \mathrm{m}^{2} ; \quad v-$ system speed, $\mathrm{m} / \mathrm{s}$.

The potential energy of the system is realized by the energy of compressed air in the tires of the wheels, takes the following form:

$$
\Pi=\frac{C_{u}}{2}\left(y-l_{\kappa} \theta\right)^{2}+\frac{C_{u}}{2}\left(y+l_{\kappa} \theta-h_{n}\right)^{2},
$$

where $C_{u}$ - radial rigidity of a semi-trailer wheel tire, $\mathrm{N} / \mathrm{m} ; \quad l_{\kappa}$ - half track of semi-trailer, $\mathrm{m}$; $h_{n}$ - lifting of the right wheel of a semi-trailer on inequalities of a sinusoidal profile, $\mathrm{m}$.

In general form can be written

$$
h_{n}=h_{0} \sin \frac{2 \pi x}{l_{0}},
$$

where $\quad h_{n}$ - висота нерівностей, $\mathrm{m} ; \quad h_{0}$ - the amplitude value of the inequality profile, $\mathrm{m} ; \quad x-$ abscissa of the approximate function of inequalities, $\mathrm{m} ; \quad l_{0}$ - length of sine wave that approximates the function of inequalities, $\mathrm{m}$.

When the system is moving

$$
x=v t .
$$

In view of expression (5), the lift of the right wheel of the semi-trailer is equal

$$
h_{n}=h_{0} \sin \frac{2 \pi v}{l_{0}} t
$$

Neglecting the forces of non-conservative origin, we substitute expressions of kinetic and potential energies in the second-kind Lagrange equation (1).

$$
\begin{gathered}
\frac{\partial \mathrm{T}}{\partial \dot{y}}=\frac{\partial}{\partial \dot{y}}\left(\frac{m_{c} \dot{y}^{2}}{2}+\frac{I_{c} \dot{\theta}^{2}}{2}+\frac{m_{c} v^{2}}{2}\right)=m_{c} \dot{y} ; \\
\frac{d}{d t}\left(\frac{\partial T}{\partial \dot{y}}\right)=\frac{d}{d t}\left(m_{c} \dot{y}\right)=m_{c} \ddot{y} ; \\
\frac{\partial \mathrm{T}}{\partial y}=\frac{\partial}{\partial y}\left(\frac{m_{c} \dot{y}^{2}}{2}+\frac{I_{c} \dot{\theta}^{2}}{2}+\frac{m_{c} v^{2}}{2}\right)=0 ;
\end{gathered}
$$




$$
\begin{aligned}
& \frac{\partial \Pi}{\partial y}=\frac{\partial}{\partial y}\left[\frac{C_{u}}{2}\left(y-l_{\kappa} \theta\right)^{2}+\frac{C_{u}}{2}\left(y+l_{\kappa} \theta-h_{n}\right)^{2}\right]= \\
& =\frac{C_{u}}{2} \cdot 2\left(y-l_{\kappa} \theta\right) \cdot 1+\frac{C_{u}}{2} \cdot 2\left(y+l_{\kappa} \theta-h_{n}\right) \cdot 1= \\
& =C_{u} y-C_{u} l_{\kappa} \theta+C_{u} y+C_{u} l_{\kappa} \theta-C_{u} h_{n}=2 C_{u} y-C_{u} h_{n} .
\end{aligned}
$$

Combining the expressions obtained, we write the first differential equation:

$$
\begin{gathered}
m_{c} \ddot{y}+2 C_{u} y=C_{u} h_{n} . \\
\frac{\partial \mathrm{T}}{\partial \dot{\theta}}=\frac{\partial}{\partial \dot{\theta}}\left(\frac{m_{c} \dot{y}^{2}}{2}+\frac{I_{c} \dot{\theta}^{2}}{2}+\frac{m_{c} v^{2}}{2}\right)=I_{c} \dot{\theta} \\
\frac{d}{d t}\left(\frac{\partial T}{\partial \dot{\theta}}\right)=\frac{d}{d t}\left(I_{c} \dot{\theta}\right)=I_{c} \ddot{\theta} \\
\frac{\partial \mathrm{T}}{\partial \theta}=\frac{\partial}{\partial \theta}\left(\frac{m_{c} \dot{y}^{2}}{2}+\frac{I_{c} \dot{\theta}^{2}}{2}+\frac{m_{c} v^{2}}{2}\right)=0 ; \\
\frac{\partial \Pi}{\partial \theta}=\frac{\partial}{\partial \theta}\left[\frac{C_{u}}{2}\left(y-l_{\kappa} \theta\right)^{2}+\frac{C_{u}}{2}\left(y+l_{\kappa} \theta-h_{n}\right)^{2}\right]= \\
=\frac{C_{u}}{2} \cdot 2\left(y-l_{\kappa} \theta\right) \cdot\left(-l_{\kappa}\right)+\frac{C_{u}}{2} \cdot 2\left(y+l_{\kappa} \theta-h_{n}\right) \cdot l_{\kappa}= \\
=-C_{u} l_{\kappa} y+C_{u} l_{\kappa}^{2} \theta+C_{u} l_{\kappa} y+C_{u} l_{\kappa}^{2} \theta-C_{u} l_{\kappa} h_{n}=2 C_{u l} l_{\kappa}^{2} \theta-C_{u} l_{\kappa} h_{n} .
\end{gathered}
$$

Combining the expressions obtained, we write the second differential equation:

$$
I_{c} \ddot{\theta}+2 C_{u} l_{\kappa}^{2} \theta=C_{u} l_{\kappa} h_{n}
$$

Rewrite the equation (7) and (8) on the basis of expression (6):

$$
\begin{gathered}
m_{c} \ddot{y}+2 C_{u} y=C_{u} h_{0} \sin \frac{2 \pi v}{l_{0}} t \\
I_{c} \ddot{\theta}+2 C_{u} l_{\kappa}^{2} \theta=C_{u} l_{\kappa} h_{0} \sin \frac{2 \pi v}{l_{0}} t .
\end{gathered}
$$

We write down equations (9) and (10) with the introduction of new notation

$$
\ddot{y}+p_{y}^{2} y=\frac{C_{u}}{m_{c}} h_{0} \sin \frac{2 \pi v}{l_{0}} t
$$

where $p_{y}^{2}=\frac{2 C_{u}}{m_{c}}-$ the square of the natural circular frequency of the system in the generalized coordinate $y, \mathrm{c}^{-2}$

$$
\ddot{\theta}+p_{\theta}^{2} \theta=\frac{C_{u l} l_{\kappa}}{I_{c}} h_{0} \sin \frac{2 \pi v}{l_{0}} t
$$

where $p_{\theta}^{2}=\frac{2 C_{m} l_{K}^{2}}{I_{c}}$ - the square of the natural circular frequency of the system in the generalized coordinate $\theta, \mathrm{c}^{-2}$.

Equations (11) and (12) have the following form:

$$
y=C_{1} \cos p_{y} t+C_{2} \sin p_{y} t+\frac{C_{u} h_{0}}{m_{c}\left(p_{y}^{2}+\frac{4 \pi^{2} v^{2}}{l_{0}^{2}}\right)} \sin \left(\frac{2 \pi v}{l_{0}} t-\psi_{1}\right),
$$




$$
\theta=C_{3} \cos p_{\theta} t+C_{4} \sin p_{\theta} t+\frac{C_{u} l_{\kappa} h_{0}}{I_{c}\left(p_{\theta}^{2}-\frac{4 \pi^{2} v^{2}}{l_{0}^{2}}\right)} \sin \left(\frac{2 \pi v}{l_{0}} t-\psi_{2}\right)
$$

The first two additions in expressions (13) and (14) describe the free oscillations of the system, which are determined by the initial conditions and, after a while, disappear. Remain forced oscillations, which are described as follows:

$$
\begin{gathered}
y=\frac{C_{u} h_{0}}{m_{c}\left(p_{y}^{2}-\frac{4 \pi^{2} v^{2}}{l_{0}^{2}}\right)} \sin \left(\frac{2 \pi v}{l_{0}} t-\psi_{1}\right), \\
\theta=\frac{C_{u l} l_{\kappa} h_{0}}{I_{c}\left(p_{\theta}^{2}-\frac{4 \pi^{2} v^{2}}{l_{0}^{2}}\right)} \sin \left(\frac{2 \pi v}{l_{0}} t-\psi_{2}\right) .
\end{gathered}
$$

Directly from expression (16) we obtain the condition of loss of stability of the semitrailer in the transverse plane during asymmetric kinematic perturbation

$$
p_{\theta}^{2}-\frac{4 \pi^{2} v^{2}}{l_{0}^{2}}=0
$$

or after opening its own circular frequency $p_{\theta}$

$$
\frac{2 C_{u} l_{\kappa}^{2}}{I_{c}}-\frac{4 \pi^{2} v^{2}}{l_{0}^{2}}=0 .
$$

From where do we get the critical speed at which the stability of a semi-trailer container carrier in the transverse plane occurs:

$$
v_{\kappa p}=\frac{l_{\kappa} l_{0}}{\pi} \sqrt{\frac{C_{u}}{2 I_{c}}} .
$$

To increase the lateral stability of the system, due to the high position of the center of mass of the container carrier, we include a stabilizer of the transverse stability in the suspension of the trailer part, which is taken into account in the calculation model by introducing equivalent stiffness of the suspension during oblique symmetry perturbations.

Again, we incorporate the second-kind Lagrange equation (1) into the mathematical model.

In this case, the system has two degrees of freedom when $q_{1}=y, q_{2}=\theta$, where $y$ - vertical movement of the semi-trailer, and $\theta$ - the angle of the semi-trailer in the transverse plane.

The kinetic energy of the system:

$$
T=\frac{m_{n} \dot{y}^{2}}{2}+\frac{I_{n} \dot{\theta}^{2}}{2}+\frac{m_{c} v^{2}}{2}
$$

where $m_{n}$ - the mass of the sprung parts of the semi-trailer, $\mathrm{kg} ; I_{n}-$ moment of inertia of the sprung parts of the semi-trailer regarding to the longitudinal axis passing through the center of mass of these parts, $\mathrm{kg} \cdot \mathrm{m}^{2} ; m_{c}$ — the total mass of the semi-trailer, $\mathrm{kg} ; v-$ system speed, $\mathrm{m} / \mathrm{s}$.

Potential energy of the system:

$$
\Pi=\frac{C_{e}}{2}\left(y-l_{\kappa} \theta\right)^{2}+\frac{C_{e}}{2}\left(y+l_{\kappa} \theta-h_{\Pi}\right)^{2}+\frac{C_{\beta}}{2} \theta^{2},
$$

where $C_{e}$ - coefficient of equivalent rigidity of the elastic suspension, $\mathrm{N} / \mathrm{m} ; \quad C_{\beta}-$ coefficient of angular stiffness of the stabilizer of lateral stability, N/m; $l_{\kappa}$ - half track of semi-trailer, $\mathrm{m} ; h_{\Pi}$ lifting of the right wheel of a semi-trailer on inequalities of a sinusoidal profile, $\mathrm{m}$. 
The coefficient of equivalent rigidity is determined by the formula

$$
C_{e}=\frac{C_{\mathrm{\amalg}} C_{\Pi}}{C_{\mathrm{\amalg}}+C_{\Pi}},
$$

where $C_{\mathrm{II}}$ - radial stiffness coefficient of suspension pneumatics, $\mathrm{N} / \mathrm{m} ; C_{\Pi}$ - the coefficient of rigidity of the suspension, $\mathrm{N} / \mathrm{m}$.

The angular stiffness coefficient of the lateral stabilizer is as follows:

$$
C_{\beta}=C_{c} \frac{l_{c}^{2}}{2},
$$

where $C_{c}$ - коефіцієнт лінійної жорсткості стабілізатора поперечної стійкості, $\mathrm{N} / \mathrm{m} ; \quad l_{c}$ the length of the stabilizer, which works on torsion at warps of the sprung parts, $\mathrm{m}$.

In general form can be written

$$
h_{\Pi}=h_{0} \sin \frac{2 \pi x}{l_{0}},
$$

where $\quad h_{\Pi}$ - height of inequalities, $\mathrm{m} ; \quad h_{0}$ - the amplitude value of the inequality profile, $\mathrm{m} ; \quad x-$ abscissa of the approximate function of inequalities, $\mathrm{m}$; $l_{0}$ - the length of a sine wave that approximates the function of inequalities, $\mathrm{m}$.

When moving the system

$$
x=v t .
$$

In view of expression (25), the lift of the right wheel of the semi-trailer is equal

$$
h_{n}=h_{0} \sin \frac{2 \pi v}{l_{0}} t .
$$

Neglecting the forces of non-conservative origin, we substitute the kinetic and potential energies in the second-kind Lagrange equation (1), and obtain the following system of equations

$$
\left.\begin{array}{l}
m_{\Pi} \ddot{y}+2 C_{e} y=C_{e} h_{0} \sin \frac{2 \pi v}{l_{0}} t \\
I_{\Pi} \ddot{\theta}+\left(2 C_{e} l_{\kappa}^{2}+C_{\beta}\right) \theta=C_{e} l_{\kappa} h_{0} \sin \frac{2 \pi v}{l_{0}} t .
\end{array}\right\}
$$

The first equation of system (27) is divided into $m_{\Pi}$, other - into $I_{\Pi}$, we get:

$$
\left.\begin{array}{l}
\ddot{y}+\frac{2 C_{e}}{m_{\Pi}} y=\frac{C_{e} h_{0}}{m_{\Pi}} \sin \frac{2 \pi v}{l_{0}} t ; \\
\ddot{\theta}+\frac{2 C_{e} l_{\kappa}^{2}+C_{\beta}}{I_{\Pi}} \theta=\frac{C_{e} l_{\kappa} h_{0}}{I_{\Pi}} \sin \frac{2 \pi v}{l_{0}} t .
\end{array}\right\}
$$

We enter the following notation:

$$
\begin{gathered}
\frac{2 C_{e}}{m_{\Pi}}=p_{y}^{2} ; \\
\frac{2 C_{e} l_{\kappa}^{2}+C_{\beta}}{I_{\Pi}}=p_{\theta}^{2} .
\end{gathered}
$$

Rewrite the system (28) with the notation (29) and (30):

$$
\left.\begin{array}{l}
\ddot{y}+p_{y}^{2} y=\frac{C_{e} h_{0}}{m_{\Pi}} \sin \frac{2 \pi v}{l_{0}} t \\
\ddot{\theta}+p_{\theta}^{2} \theta=\frac{C_{e} h_{0} l_{\kappa}}{I_{\Pi}} \sin \frac{2 \pi v}{l_{0}} t
\end{array}\right\}
$$

The solutions of equations (31) are given 


$$
\begin{gathered}
y=C_{1} \cos p_{y} t+C_{2} \sin p_{y} t+\frac{h_{0} p_{y}^{2}}{2\left(p_{y}^{2}-\frac{4 \pi^{2} v^{2}}{l_{0}^{2}}\right)} \sin \left(\frac{2 \pi v}{l_{0}} t-\psi_{1}\right) ; \\
\theta=C_{3} \cos p_{\theta} t+C_{4} \sin p_{\theta} t+\frac{C_{e} h_{0} l_{k} p_{\theta}^{2}}{\left(2 C_{e} l_{k}^{2}+C_{\beta}\right)\left(p_{\theta}^{2}-\frac{4 \pi^{2} v^{2}}{l_{0}^{2}}\right)} \sin \left(\frac{2 \pi v}{l_{0}} t-\psi_{2}\right) .
\end{gathered}
$$

In expressions (32) and (33), the first two additions describe the free oscillations of a fastdecaying system and cannot be taken into account. In this case, the solution of equations (31) can be written as follows:

$$
\begin{gathered}
y=\frac{h_{0} p_{y}^{2}}{2\left(p_{y}^{2}-\frac{4 \pi^{2} v^{2}}{l_{0}^{2}}\right)} \sin \left(\frac{2 \pi v}{l_{0}} t-\psi_{1}\right), \\
\theta=\frac{C_{e} h_{0} l_{k} p_{\theta}^{2}}{\left(2 C_{e} l_{k}^{2}+C_{\beta}\right)\left(p_{\theta}^{2}-\frac{4 \pi^{2} v^{2}}{l_{0}^{2}}\right)} \sin \left(\frac{2 \pi v}{l_{0}} t-\psi_{2}\right),
\end{gathered}
$$

where $\psi_{i}$ - phase angle, rad.

From these solutions, we write the condition of loss of stability of the system in transverse oscillations at skew symmetry perturbations.

$$
p_{\theta}^{2}-\frac{4 \pi^{2} v^{2}}{l_{0}^{2}}=0
$$

or after disclosure $p_{\theta}^{2}$ :

$$
\frac{2 C_{e} l_{\kappa}^{2}+C_{\beta}}{I_{\Pi}}-\frac{4 \pi^{2} v^{2}}{l_{0}^{2}}=0 .
$$

Where do we get the critical speed at which the system loses stability.

$$
v_{\kappa p}=\frac{l_{0}}{2 \pi} \sqrt{\frac{2 C_{e} l_{\kappa}^{2}+C_{\beta}}{I_{\Pi}}} .
$$

\section{Conclusions and prospects for further research}

As a result of the theoretical study of the dynamics of a articulated container ship with a tow frame on a pneumatic wheel, a mathematical model of perturbed motion in the transverse plane was developed taking into account the different level of stabilization of the trailer on the basis of the mathematical apparatus of analytical mechanics with engaging.

The developed mathematical model of the perturbed motion in the transverse plane is the basis for determining the critical speed of movement of the container vessel in the absence and presence of the stabilizer of the transverse stability.

In further studies of container ships with a tow frame on a pneumatic wheel it is necessary to work in the direction of development of new types of stabilizers of cross resistance with rational metal content, structural perfection.

\section{References}

[1] Griff M.I., Zatvan R.A., Trofimenko V.F. Avtotransportnye sredstva s gruzopodyomnimy ustroistvamy dlia perevozky $v$ konteinerah i paketah [Motor-vehicle transport means with lifting power gear for load transportation in containers and packets]. Moscow, 1989, 159 p. (in Russian). 
[2] Grushnikov V.A. Vibor transportnih sredstv dlia conteinernoy dostavky stroitelnyh gruzov [Selection of transportal means for container lift of structural loads]. Industrial transport, 1987, no.11, p.7 (in Russian).

[3] Pashkov A.K., Polyarin Y.N. Paketirovanye i perevozka tarnoshtuchnih gruzov [Piling and transportation of container loads]. Moscow, 200, 254 p. (in Russian).

[4] Zolotaryov A.F., Totskiy I.A. Konteinerovoz na baze tractora T-150K [Container truck by base tractor T-150K]. Industrial transport, 1979, no. 6, p. 22 (in Russian).

[5] Beygul O.A., Korniychuk M.M.,Lepetova A.L., Nayda D.V. Doslidzhennia ta vibir tipu nesuchoyi sustemy avtoskrapovoza z U- podibnoyu ramoyu [Investigation and selection of loadcarrying system container truck with U-similar frame type]. Reliability of metallurgical equipment: Sciences works of International conference 28-31.10.2013. pp. 138-141 (in Ukrainian).

[6] Malinovskiy E.Y., Gaytsgory M.M. Dinamika samohodnih mashin s sharnirnoy ramoy (Kolebaniya i ustoichivost dvizheniya) [Dynamics of automotive vechicles with hinger frame (vibrations and stability of traffic)]. Moscow, 1974, 172p. (in Russian).

[7] Veselov H.P., Hustomyasov A.N., Kolmacov V.I. Analiticheskoye issledovaniye kolebaniy sistemy «tiagach-pritsep» [Analytical investigation of system «tractor-trailer» vibrations]. News of universities: Engineering, 1988, no. 5 pp. 92-97 (in Russian).

[8] Lobas L.H., Vaschenko Y.L. Dinamicheskoye povedeniye dvuhzvennogo avtopoezda vblizy granitsy oblasty ustoichivosty [Dynamical behaviour of twin-section motor-vehicle by boundary line stability]. Applied mathematic, 1991, no. 12, pp. 85-91 (in Russian).

[9] Beygul V.O., Leepa I.I., Lepetova A.L. Matematichna model zburenogo ruhu sustemy «buksirovschyk-avtosamockyd» [Mathematical model of disturbance motion for system «motor tugmining rear dumper»]. Sciences works «system technology», 2006, no.4(45), pp. 94-98 (in Ukrainian).

[10] Beygul O.A., Lepetova A.L. Dinamika zburenogo ruchu zchlenovanogo spetsavtotransportnogo zasobu z U-podibnoyu vantazhnoyu ramoyu [Dynamics of articulated special transport with band loop load frame motion distorbance]. Sciences works KSSTU: Mechanics of hard body, 2013, no.15, pp. 15-20 (in Ukrainian).

[11] Yablonskiy A.A., Noreico S.S. Curs teoriy kolebaniy [Science of vibrations theory]. Moscow, 1966, 255p. (in Russian).

[12] Bronshtein I.N., Semendiaev K.A. Spravochnik po matematike dlia inzhenerov i uchaschihsia vtuzov [Mathematical reference book for engineers and students of technical university]. Moscow, 1986, 544p. (in Russian).

\section{ДОСЛІДЖЕННЯ ПОПЕРЕЧНОЇ СТІЙКОСТІ БУГЕЛЬНИХ НЕСУЧИХ СИСТЕМ ЗЧЛЕНОВАНИХ КОНТЕЙНЕРОВОЗІВ ПРИ РУСІ ПО ТЕХНОЛОГІЧНИХ ДОРОГАХ \\ Бейгул О.О., Грищенко Д.І., Бейгул В.О., Середа Д.Б.}

\section{Реферат}

Мета роботи - отримання нових співвідношень у математичній моделі збуреного руху зчленованого контейнеровоза з бугельною рамою на пневмоколісному ході під час руху технологічними дорогами промислових підприємств. Основним джерелом збурень $є$ кососиметричні кінематичні збурення з боку нерівностей покриття технологічних доріг, які апроксимуються гармонічними функціями вздовж колії. Основою математичного апарату теоретичного дослідження $\epsilon$ методологія аналітичної механіки з використанням рівняння Лагранжа другого роду. Об'єкт дослідження зводиться до динамічної системи з двома ступенями свободи, де узагальнені координати представлені лінійними та кутовими переміщеннями несучої системи контейнеровоза, що призводить до складання двох диференціальних рівнянь руху. Права частина цих рівнянь описує параметри кінематичних збурень. 3 розв'язання диференціальних рівнянь збу- 
реного руху контейнеровоза 3 бугельною рамою за наявності кососиметричних кінематичних збурень виходять власні динамічні характеристики системи, умова стійкості при поперечних коливаннях зчленованого контейнеровоза, отримується умова для визначення критичної швидкості, при якій система втрачає стійкість. Розроблена математична модель сприяє активному втручанню на стадії проектування у параметри коливань зчленованого контейнеровоза $з$ бугельною рамою на пневмоколісному ході шляхом вибору відповідних жорсткісних характеристик стабілізатора поперечної стійкості. Отримані співвідношення демонструють алгоритм впливу на параметри системи на етапі розробки конструкції з метою створення ідеальної моделі зчленованого контейнеровоза з бугельною рамою на пневмоколісному ході, що гарантує велику практичну значимість дослідження.

\section{Література}

1. Грифф М.И., Затван Р.А., Трофименко В.Ф. Автотранспортные средства с грузоподъемными устройствами для перевозки грузов в контейнерах и пакетах. М.: Транспорт, 1989. 159 с.

2. Грушников В.А. Выбор транспортных средств для контейнерной доставки строительных грузов. Промышиенный транспорт. 1987. №11. С. 7.

3. Пашков А.К., Полярин Ю.Н. Проектирование и перевозка тарно-штучных грузов. М.: Транспорт, 2000. $254 \mathrm{c}$.

4. Золотарев А.Ф., Тоцкий И.А. Контейнеровоз на базе трактора Т-150К. Промышленный транспорт. 1979. №6. С. 22.

5. Дослідження та вибір типу несучої системи автоскраповоза з U-подібною рамою / О.О. Бейгул та ін. Надійність металургійного обладнання: Зб. наук. праць з мат. Міжнар. наук.-прак. конф., м. Дніпропетровськ, 28-31 жовтня 2013p. / НМетАУ. Дніпропетровськ: НМетАУ, 2013. С. 138-141.

6. Малиновский Е.Ю., Гайцгори М.М. Динамика самоходных машин с шарнирной рамой (колебания и устойчивость движения). М.: Машиностроение, 1974. 172 с.

7. Веселов Г.П., Густомясов А.Н., Колмаков В.И. Аналитическое исследование колебаний системы тягач-прицеп. Известия вузов. Машиностроение. 1988. №5. С. 92-97.

8. Лобас Л.Г., Ващенко Ю.Л. Динамическое поведение двухзвенного автопоезда вблизи границы области устойчивости. Прикладная математика. 1991. Т.27. №12. С. 85-91.

9. Бейгул В.О., Лєєпа І.І., Лепетова Г.Л. Математична модель збуреного руху системи «буксировщик-автосамоскид». Системні технології. 2006. Вип. 4(45). С. 94-98.

10. Бейгул О.О., Лепетова Г.Л. Динаміка збуреного руху зчленованого спецавтотранспортного засобу з U-подібною вантажною рамою: сб. науч. тр. КГМТУ «Механика твердого тела. Механизация производственных процессов рыбного хозяйства, промышленных и аграрных предприятий». Керь: КГМТУ, 2013. Вып. 15. С. 15-20.

11. Яблонский А.А., Норейко С.С. Курс теории колебаний. М.: Высшая школа, 1966. 255 с.

12. Бронштейн И.Н., Семендяев К.А. Справочник по математике для инженеров и учащихся втузов. 13-е изд., испр. М.: Наука, 1986. 544 с. 